\title{
Experimental investigation of secondary use of punched metal plate fasteners in timber structures
}

\author{
Mantas Stulpinas ${ }^{1}$, Tomas Gečys ${ }^{2}$ \\ Department of Steel and Composite Structures, Faculty of Civil Engineering, \\ Vilnius Gediminas Technical University, Vilnius, Lituania \\ E-mail: ' ${ }^{2}$ antas.stulpinas@stud.vgtu.lt (corresponding author)
}

\begin{abstract}
In this article, the possibility of secondary use of punched metal plate fasteners for timber structures is experimentally investigated. The secondary used metal plate fasteners are experimentally tested in both positions, parallel and perpendicular to the timber grain. For this purpose, the tension-to-tension test setup is used. Laboratory experiments of the secondary used metal plate fasteners are performed in parallel with the corresponding connection with the same size new metal plate fastener. All specimens for laboratory experiments are prefabricated at the factory. Laboratory experiments are done with an aim to investigate both, the reduction of the load bearing capacity and the stiffness, when metal plate fasteners are secondary used. In this article, the main design principles of joints with metal plate fasteners according to the Eurocode 5, are also discussed. The comparison between the strength and stiffness of the firstly and secondary used joints is provided. The comparison between the experimental and theoretical strength and stiffness calculation results according to the Eurocode 5 is provided too. The received results show high potential for the future research in secondary used punched metal fasteners, as the reduction of the strength and stiffness is around 20 percent, comparing with the first time used fasteners.
\end{abstract}

Keywords: punched metal plate fasteners, timber structures, secondary used fasteners.

\section{Introduction}

This article was inspired by the climate change, currently happening on the Earth. The planet's global temperature has risen by $1.1{ }^{\circ} \mathrm{C}$ since 1880 year and every decade at least 12.8 percent of the Arctic ice melts (NASA, 2014). There are a few types of gases, that contribute to greenhouse effect (a process that warms the surface) - water vapor, nitrous oxide, methane, carbon dioxide. The latter are released through the natural processes such as respirations and volcano eruptions, also through the human activities such as deforestation, land use changes and burning fossil fuels. The human race have increased the atmospheric carbon dioxide concentration by more than a third since the Industrial Revolution began. This is the most important long-lived "forcing" of climate change (NASA, 2014). While steel industry made a high progress in production effectiveness (Kundak, Lazic, \& Crnko, 2009), it is still the most carbon dioxide emitting industry (Figure 1a). Production of iron and steel worldwide is responsible for 7 to 9 percent of all direct emissions from fossil fuels (Alter, 2019). While being 100\% recyclable, steel industry has full potential being a circular economy. While recycling of steel scraps is more energy efficient by up to $60 \%$ than producing the steel fresh and avoids up to 75\% of carbon dioxide emission (World Steel Association, 2015), becoming a circular economy not only recycling of all wastes. New generation circular economy encompass all aspects of resource efficiency from production to consumption (Nae Hee Han, 2018) (Figure 1b).

In this article the possibility of remanufacture of timber structures using the punched metal plate fasteners is experimentally investigated. Punched metal plate fasteners for a secondary use could be available from used formwork support structures which were used in concreting process. Most commonly timber structures with punched metal plate fasteners are used for uneven form of concrete bridges as supporting structure of formwork. After the concreting process is finished, there is a lot of waste of timber structures with punched metal plate fasteners. The construction of one of the bridges built in Lithuania applied around 11.9 tonnes of punched metal plate fasteners.

Further this article shows the experimental investigation results of the secondary used punched metal plate fasteners which were extracted from the used formwork timber structures. The Eurocode 5 gives calculation methods for timber structures, assembled using new punched metal plate fasteners. Prievious investigations were done on punched metal plate fasteners (Žikica \& Saša, 2014; Tinozivashe \& Zhongwei, 2011; Ellegaard, 2006) with an aim to 


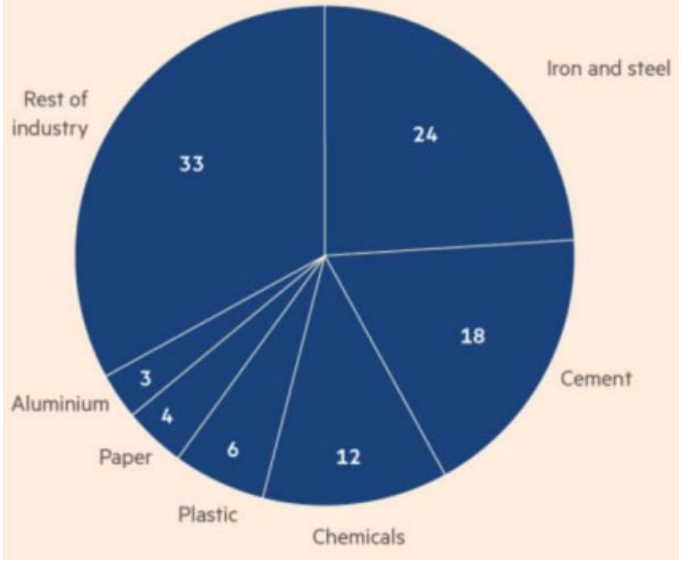

a)

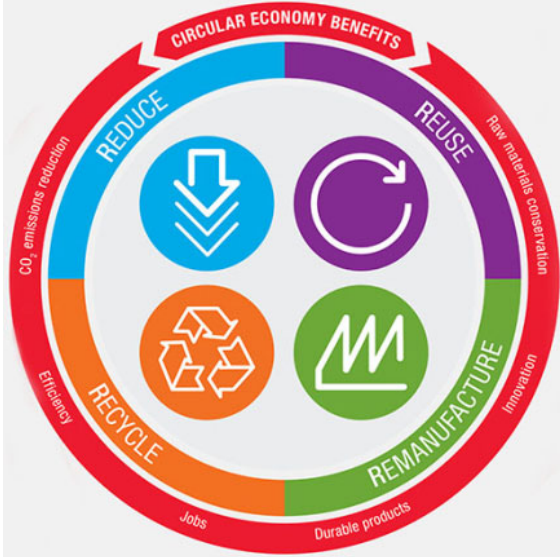

b)

Figure 1. a) total industry $\mathrm{CO}_{2}$ emission (Alter, 2019); b) circular economy (World Steel Association, 2015)

compare experimental investigations with theoretical assumptions. The performance of punched metal plate fasteners in fire conditions were previously investigated too (Jurgelionis, 2011). The literature review on the analysed topic shows that there were no investigations previously done on the secondary used punched metal plate fasteners.

\section{Preparation of test specimens}

In order to produce timber structures with secondary used punched metal plate fasteners, these fasteners had to be removed from the used structure. A tool and a technology that are being patented (patent application no.: LT2018 569) was used (Mykolaitis, 2018). A patented tool was used to mechanically pull the fastener out of the timber, as shown in Figure 2a. At first, one side of the fastener is pulled out using a screwdiver. Then, while holding the pulled out side, whole fastener is extracted by rolling it over with the tool. The fastener gets damaged during the process - it bends according to the form of roll, some of its teeth get bent. The bent tenons are not straightened. All the remaining wood fibers between fastener's teeth, if present, were removed. Then fasteners were mechanically straightened, using a simple hand-made tool. Thin plate needs to be placed between fastener teeth and pressed to unbend the fastener. The whole process of preparing a metal plate fastener for a secondary use is shown in Figure 2 .

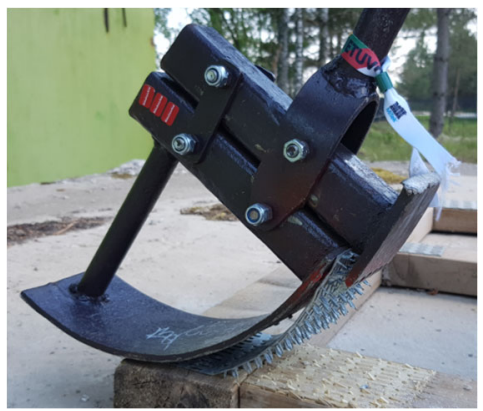

a)

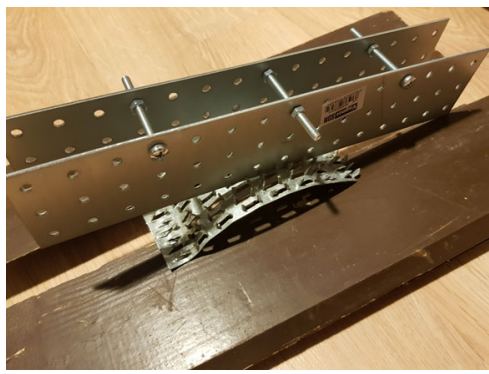

c)

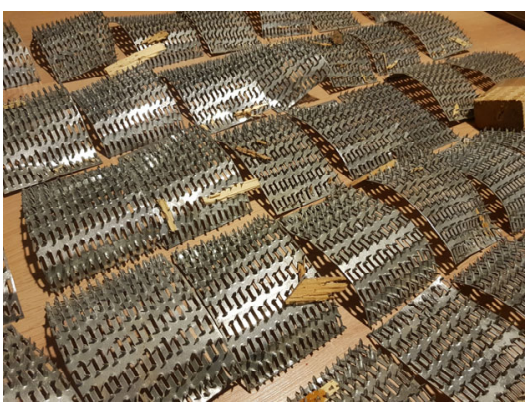

b)

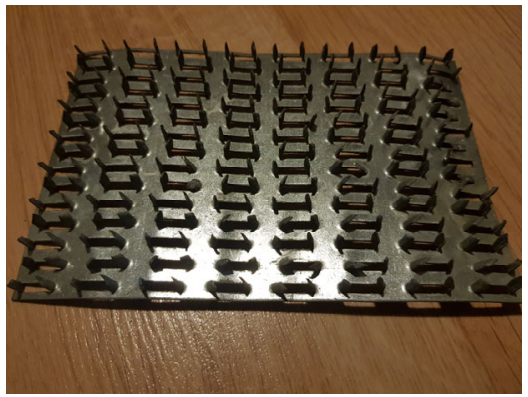

d)

Figure 2. Preparation of punched metal plate fasteners for a secondary use: a) - extraction of a fastener from a used structural member; b) - used and then extracted punched metal plate fasteners; c) - preparation for straightening of a punched metal plate fastener; d) - metal plate fastener prepared for a second use 


\section{Laboratory experimental investigations}

The main aim of the laboratory experimental investigations was to compare the strength and stiffness values of the timber structural members connected with: the new and the secondary used punched metal plate fasteners. The corresponding new connections are tested for comparison of the test results between the secondary used and the new fasteners.

Two types of connections were investigated, both in tension. The main axis of the punched metal plate fastener is assumed to be parallel with the force action direction for both types of joints.

Test specimen type $A$ was designed so that the failure of the joint would occur in the anchorage area of the punched metal plate fastener parallel to the grain, test specimen type $B$ - so that failure of the joint would occur in the anchorage area of the punched metal plate fastener perpendicular to the grain. To receive such results, the punched metal plate fasteners were GNT100 103x159, $1 \mathrm{~mm}$ thickness for type $A$ specimen and GNT $73 \times 159,1 \mathrm{~mm}$ thickness for type $B$ specimen, both were products of MiTek Industries. The same size of punched metal plate fasteners is assumed for both: the new one and the secondary use. Standard timber - was used C24 strength class according to EN 338. The rectangular cross section of $45 \times 245 \mathrm{~mm}$ for type $A$ specimen and the rectangular cross section of $45 \times 195 \mathrm{~mm}$ connected parallelly to the applied force. The rectangular cross section of $45 \times 95 \mathrm{~mm}$ connected perpendiculary to the applied force for specimen of type $B$. Test specimen of type $A$ is shown in Figure $3 \mathrm{a}$ and c, test specimen of type $B$ is shown in Figure $3 \mathrm{~b}$ and $\mathrm{d}$.

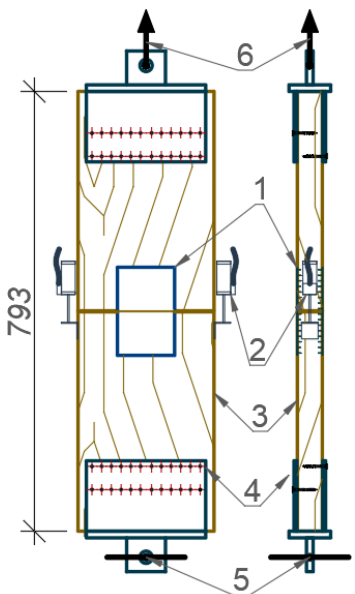

a)

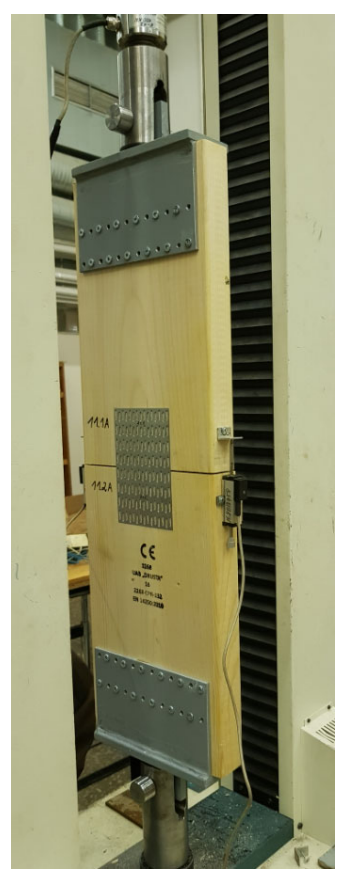

c)

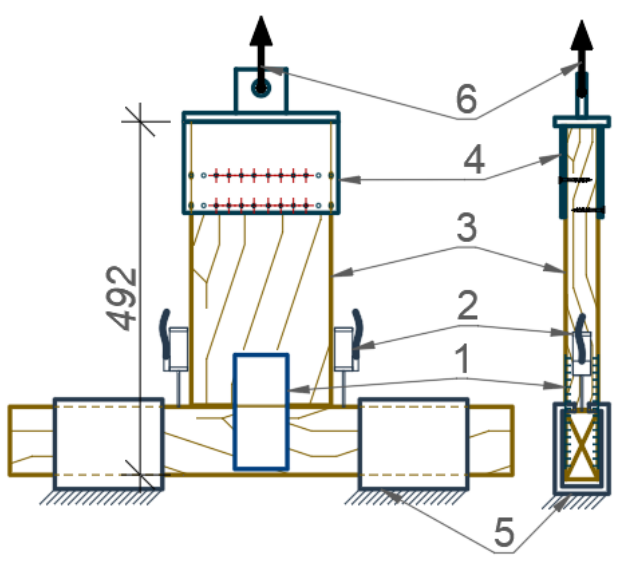

b)

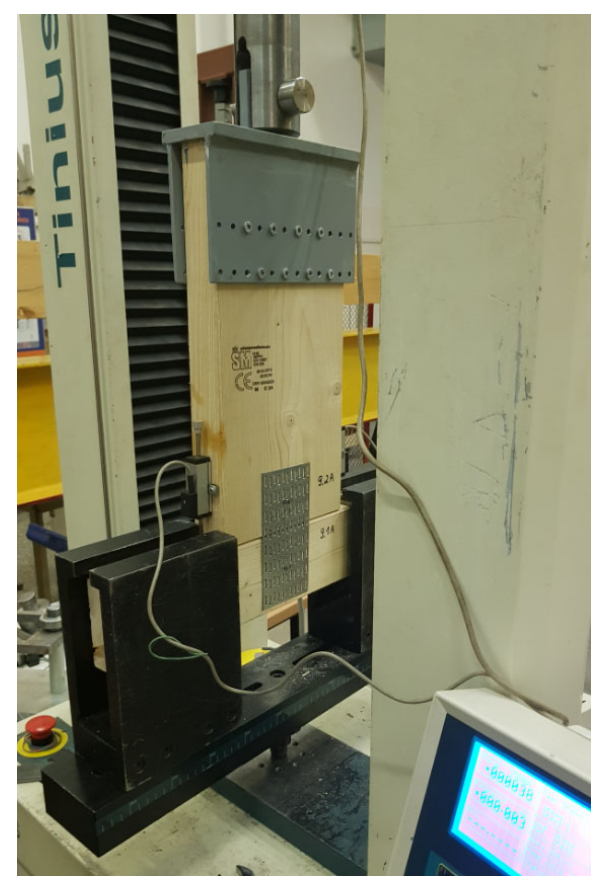

d)

Figure 3. Test specimen composition: a), c) - type $A$ specimen; b), d) - type $B$ specimen. 1 - punched metal plate fastener; 2 - displacement indicator; 3 - timber members; 4 - anchorage components; 5 - support; 6 - loading point and direction 
Experimental ivestigations were done according to the procedure provided in standard EN 26891. Every specimen was uniformly loaded up tp $40 \%$ of estimated load and maintained for $30 \mathrm{~s}$. The load then was reduced to $10 \%$ of the estimated load and maintained for $30 \mathrm{~s}$. Thereafter the load was increased until the ultimate load was reached.

Each type of specimen consist of 5 specimens with new fasteners and 7 specimens with secondary used fasteners, in total 24 test specimens. Experimental results in terms of load bearing capacity and slip modulus, are listed in Table 1 and Table 2, accordingly.

Table 1. Test results for type $A$ specimens

\begin{tabular}{|c|c|c|c|c|c|}
\hline $\begin{array}{l}\text { Specimen } \\
\text { No. }\end{array}$ & $\begin{array}{l}\text { Max. load } \\
\mathrm{F}_{\max }, \mathrm{kN}\end{array}$ & $\begin{array}{l}\text { Slip modulus } K_{\text {ser, }} \\
\mathrm{kN} / \mathrm{mm}\end{array}$ & $\begin{array}{c}\text { Average max. load, } \\
\mathrm{kN} / \mathrm{SD}, \%\end{array}$ & $\begin{array}{l}\text { Average slip modulus, } \\
\mathrm{kN} / \mathrm{mm} / \mathrm{SD}, \%\end{array}$ & Notes \\
\hline 1 & 37.87 & 41.34 & \multirow{7}{*}{$\begin{array}{c}37.87 / \\
16.5\end{array}$} & \multirow{7}{*}{$\begin{array}{c}44.17 / \\
21.7\end{array}$} & Secondary fasteners \\
\hline 2 & 49.30 & 62.75 & & & Secondary fasteners \\
\hline 3 & 40.95 & 46.38 & & & Secondary fasteners \\
\hline 4 & 29.70 & 33.54 & & & Secondary fasteners \\
\hline 5 & 32.73 & 39.31 & & & Secondary fasteners \\
\hline 6 & 36.69 & 48.19 & & & Secondary fasteners \\
\hline 7 & 37.85 & 37.65 & & & Secondary fasteners \\
\hline 8 & 49.30 & 53.16 & \multirow{5}{*}{$\begin{array}{c}49.65 / \\
8.6\end{array}$} & \multirow{5}{*}{$\begin{array}{c}53.78 / \\
13.4\end{array}$} & New fasteners \\
\hline 9 & 56.67 & 64.31 & & & New fasteners \\
\hline 10 & 46.58 & 46.40 & & & New fasteners \\
\hline 11 & 49.85 & 56.82 & & & New fasteners \\
\hline 12 & 45.87 & 48.19 & & & New fasteners \\
\hline
\end{tabular}

Table 2. Test results for type $B$ specimens

\begin{tabular}{|c|c|c|c|c|c|}
\hline $\begin{array}{l}\text { Specimen } \\
\text { No. }\end{array}$ & $\begin{array}{l}\text { Max. load } \\
F_{\max }, \mathrm{kN}\end{array}$ & $\begin{array}{l}\text { Slip modulus } K_{\text {ser, }} \\
\mathrm{kN} / \mathrm{mm}\end{array}$ & $\begin{array}{c}\text { Average max. load, } \\
\text { kN / SD, } \%\end{array}$ & $\begin{array}{c}\text { Average slip modulus, } \\
\mathrm{kN} / \mathrm{mm} / \mathrm{SD}, \%\end{array}$ & Notes \\
\hline 1 & 17.46 & 19.08 & - & - & $\begin{array}{c}\text { Secondary fasteners. } \\
\text { Results excluded be- } \\
\text { cause of failure in an- } \\
\text { chorage }\end{array}$ \\
\hline 2 & 30.97 & 25.53 & \multirow{6}{*}{$\begin{array}{c}23.64 / \\
15.8\end{array}$} & \multirow{6}{*}{$\begin{array}{c}21.98 / \\
14.6\end{array}$} & Secondary fasteners \\
\hline 3 & 21.74 & 23.44 & & & Secondary fasteners \\
\hline 4 & 23.27 & 20.34 & & & Secondary fasteners \\
\hline 5 & 23.49 & 25.32 & & & Secondary fasteners \\
\hline 6 & 21.71 & 18.02 & & & Secondary fasteners \\
\hline 7 & 20.68 & 19.23 & & & Secondary fasteners \\
\hline 8 & 28.64 & 20.62 & \multirow{5}{*}{$\begin{array}{c}27.90 / \\
4.8\end{array}$} & \multirow{5}{*}{$\begin{array}{c}19.38 / \\
5.7\end{array}$} & New fasteners \\
\hline 9 & 28.34 & 17.58 & & & New fasteners \\
\hline 10 & 29.13 & 19.65 & & & New fasteners \\
\hline 11 & 25.72 & 19.69 & & & New fasteners \\
\hline 12 & 27.65 & 19.38 & & & New fasteners \\
\hline
\end{tabular}

The average load capacity for type $A$ joints with new metal plate fasteners was $49.65 \mathrm{kN}$ with a standard deviation of $8.6 \%$, while with secondary used fasteners $-37.87 \mathrm{kN}$ with a standard deviation of $16.5 \%$. For type $B$ joints with new metal plate fasteners was $27.90 \mathrm{kN}$ with a standard deviation of $4.8 \%$, while with secondary used fasteners $-23.64 \mathrm{kN}$ with a standard deviation of $15.8 \%$. The decrease of load bearing capacity for type $A$ joints was $23.7 \%$ and $15.3 \%$ for type $B$ joints when using secondary used metal plate fasteners instead of new ones.

The average slip modulus for type $A$ joints with new metal plate fasteners was $53.78 \mathrm{kN} / \mathrm{mm}$ with a standard deviation of $13.4 \%$, while with secondary used fasteners $-44.17 \mathrm{kN} / \mathrm{mm}$ with a standard deviation of $21.7 \%$. For type $B$ joints - with new metal plate fasteners was $19.38 \mathrm{kN} / \mathrm{mm}$ with a standard deviation of $5.7 \%$, while with secondary used fasteners $-21.98 \mathrm{kN} / \mathrm{mm}$ with a standard deviation of $14.6 \%$. Slip modulus decreased by $17.9 \%$ for type $A$ joints and increased by $11.8 \%$ for type $B$ joints when using secondary used metal plate fasteners instead of new ones. The load versus deformation behaviour of the connections are shown in Figure 4. 


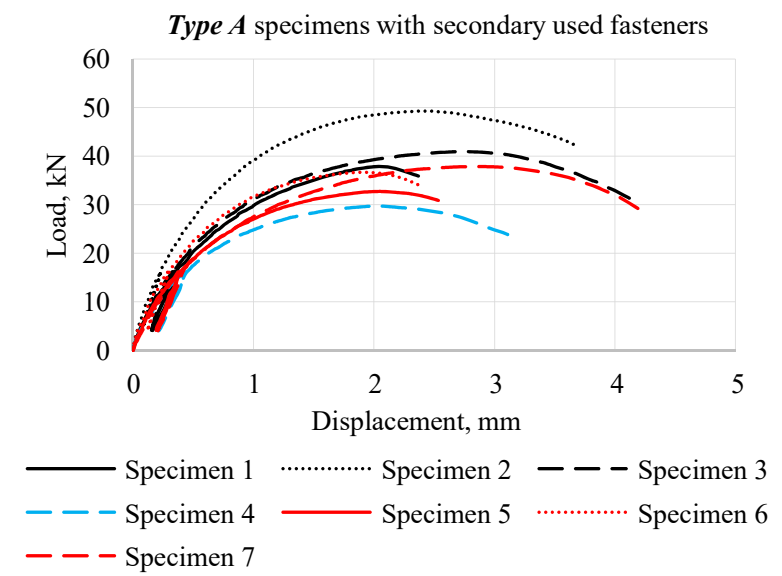

a)

Type $\boldsymbol{B}$ specimens with secondary used fasteners

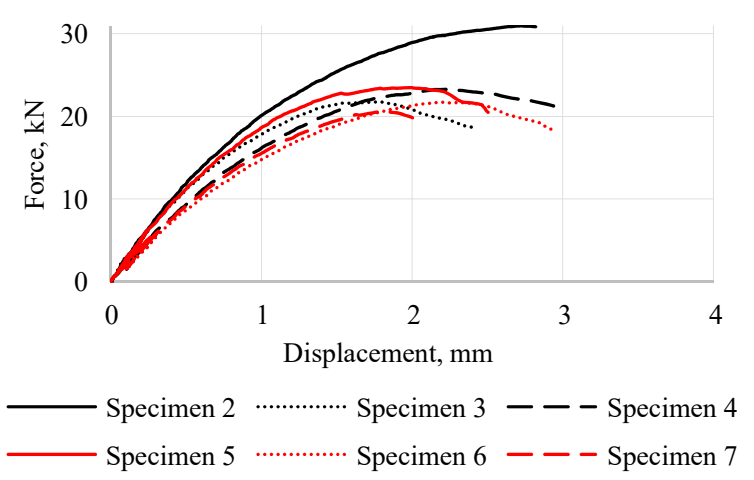

c)

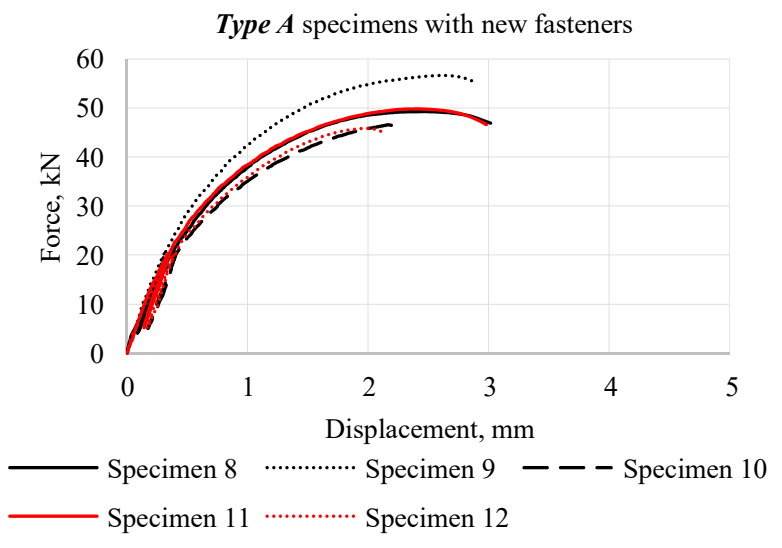

b)

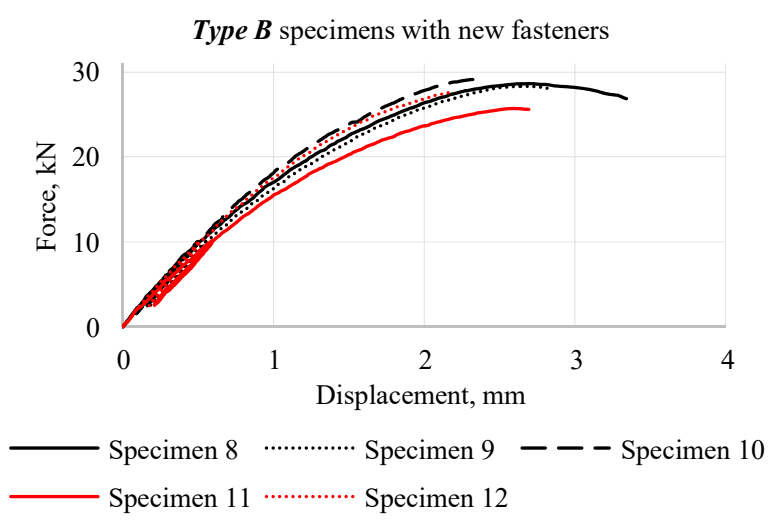

d)

Figure 4. The loadversus displacement curves: a) - type $A$ specimens with the secondary used fasteners; b) - type $A$ specimens with the new fasteners; c) - type $B$ specimens with the secondary used fasteners; d) - type $B$ specimens with the new fasteners

The experimental results show, that the usage of the secondary used metal plate fasteners for joints subjected to tension, where the main axis of plate is directioned according to the force direction, the anchorage capacity reduces by $\sim 20 \%$. The stiffness of joint is reduced by $\sim 20 \%$ aswell, while the stiffness of joints with tension perpendicular to the grain slightly increases. The scatter of results is twice higher for connections with secondary used metal plate fasteners which could be treated as a results of metal plate fastener extraction process.

Deformations of Type $A$ joints with secondary used fasteners at maximum force varied from $1.923 \mathrm{~mm}$ to $2.928 \mathrm{~mm}( \pm 0.503 \mathrm{~mm} ; \pm 20.7 \%)$ and the average was about $2.324 \mathrm{~mm}$ at failure moment. Deformations in connections with new fasteners, varied in range of $1.995 \mathrm{~mm}$ to $2.626 \mathrm{~mm}( \pm 0.316 \mathrm{~mm} ; \pm 13.7 \%)$ with the average value equal to $2.327 \mathrm{~mm}$ The latter value is more or less equal to secondary used fasteners. Deformations of type $B$ joints with secondary used fasteners at maximum force varied from $1.779 \mathrm{~mm}$ to $2.721 \mathrm{~mm}( \pm 0.471 \mathrm{~mm} ; \pm 20.9 \%)$ and the mean value was $2.130 \mathrm{~mm}$.

Different failure modes were observed during the experimental investigations, as shown in Figure 5. Both specimens of type $A$, secondary used and new metal plate fasteners, failed in the same way, the anchorage of fastener (Figure 5c). Also, two of five specimens with new fasteners failed in the anchorage along with block shear in one of the timber elements (Figure 5d). Specimens of type $B$ had few different failure modes. Most of them (7 out of 12) failed in the anchorage of fastener of perpendicular timber element (Figure 5a). The anchorage failure is resulted by pulling out the metal plate fastener of the timber. The failure in anchoage starts at the end corner of the plate, which results in decreased effective anchorage area. Results of Type B specimen No. 1 have not been used in further calculations and analysis, since the observed failure was in the compression perpendicular to the grain at the anchorage support of the whole specimen. The anchorage solution was revised by increasing the diemensions of anchorage area so that the compression perpendicular to the grain was avoided in further tests. The splitting of timber perpendicular to the grain caused by the tension force component was observed for specimen No. 2, as shown in Figure $5 \mathrm{~b}$. 


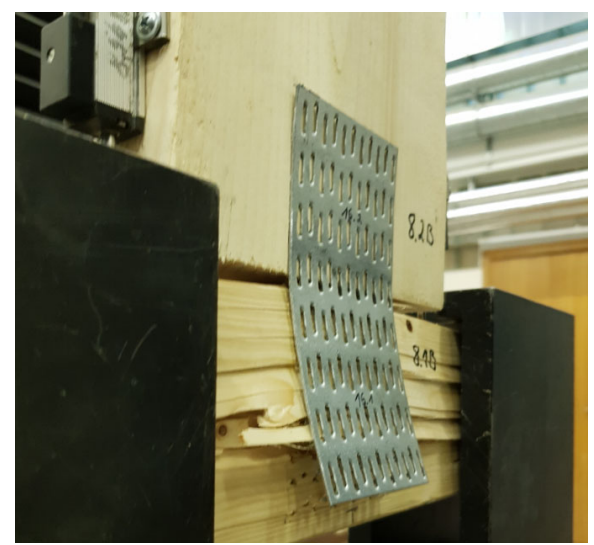

a)

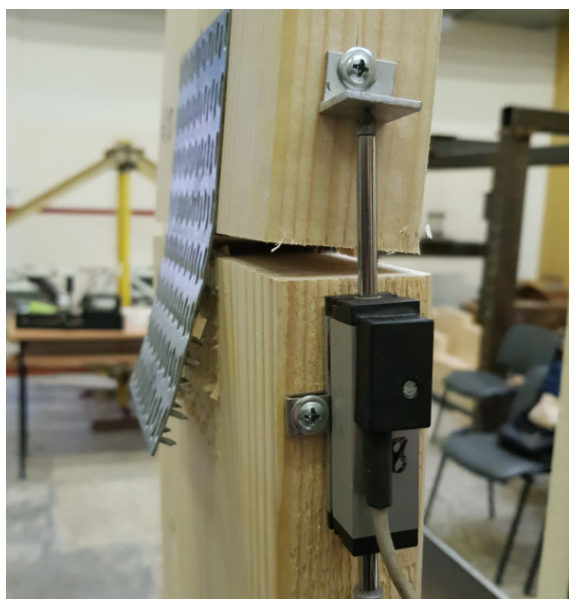

c)

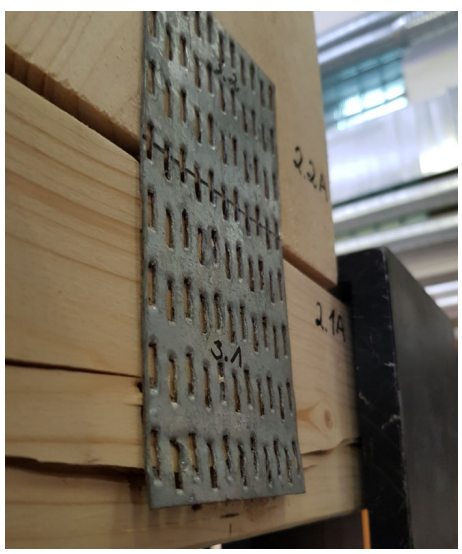

b)

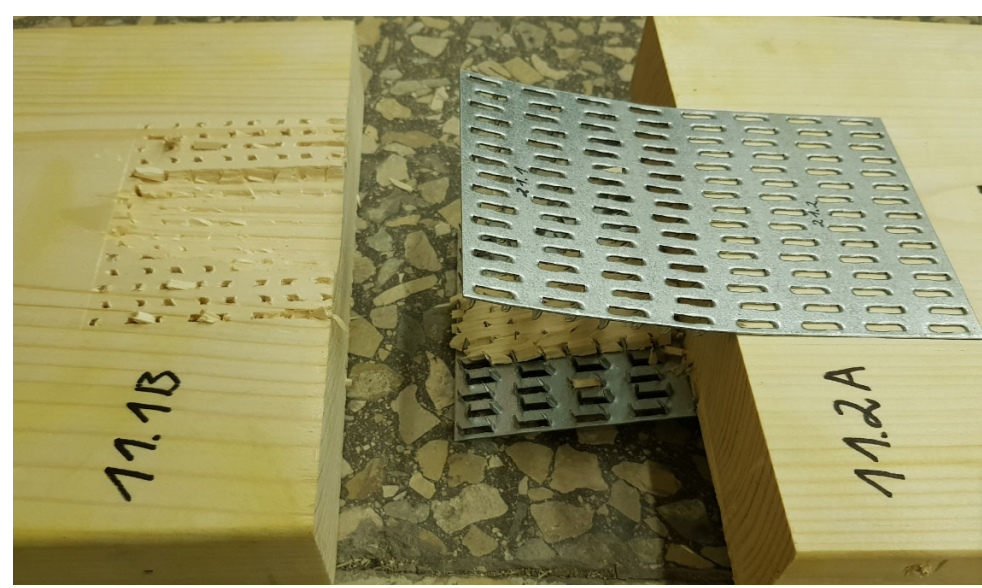

d)

Figure 5. Failure modes of test specimens: a) - failure of fastener's anchorage in timber perpendicular to it's grains, followed by failure in splitting; b) - failure in splitting; c) - failure of fastener anchorage in timber parallel to grains; d) - failure of fastener anchorage in timber parallel to grains together with failure in block shear

\section{Calculations according to Eurocode 5, evaluation of experimental and theoretical results}

The usage of the secondary used punched metal plate fasteners is not discussed in Eurocode 5. In this section only plate fastener anchorage capacity is calculated as it was the object of research. To compare the laboratory experimental results with the theoretical values, calculations according to Eurocode 5 have been done. Calculations for stiffness of a joint with punched metal plate fasteners in Eurocode 5 are not given. Therefore the slip modulus for result comparisons is calculated from the producer's Declaration of Performance (MiTek, 2013) of tested fasteners. When the joint with the metal plate fasteners is subjected to tension force, plate anchorage capacity is calculated as:

$$
\left(\frac{\tau_{F, k}}{f_{a, \alpha, \beta, k}}\right)^{2} \leq 1,
$$

where: $f_{a, \alpha, \beta, k}$ - characteristic anchorage strength per plate; $a$ - stands for punched metal plate anchorage capacity; $\alpha$ - angle between the main axis of fastener and the force; $\beta$ - angle between the timber grain direction and the force; $k$-stands for a characteristic value; $\tau_{F, k}$ - characteristic anchorage stress, imposed by the force, calculated as:

$$
\tau_{F, k}=\frac{F_{A, E k}}{A_{e f}},
$$

where: $F_{A, E k}$ - characteristic force, acting on a single plate at the centroid of effective area; $A_{e f}$ - effective plate area, calculated according to EN 1075 .

The results of the calculated characteristic anchorage capacity in tension, as well as comparison of that with the laboratory experiment results, are shown in Table 3. 
Table 3. Maximum load capacity according to calculations and experimental results

\begin{tabular}{|c|c|c|c|c|c|c|}
\hline Joint & 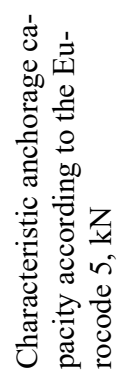 & 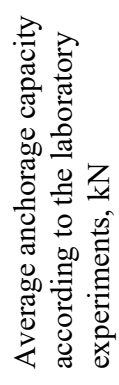 & 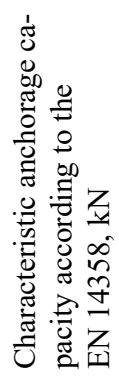 & 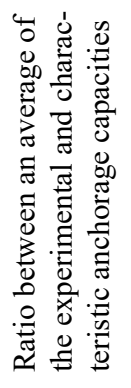 & 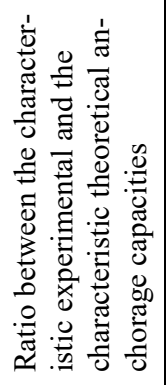 & 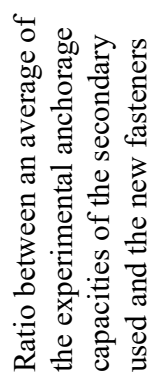 \\
\hline Type $A$ secondary used fasteners & 19.6 & 37.87 & 22.49 & 1.93 & 1.15 & \multirow{2}{*}{0.76} \\
\hline Type $A$ new fasteners & 19.6 & 49.65 & 39.13 & 2.53 & 2.00 & \\
\hline Type $B$ secondary used fasteners & 9.1 & 23.64 & 14.44 & 2.60 & 1.59 & \multirow{2}{*}{0.85} \\
\hline Type $B$ new fasteners & 9.1 & 27.90 & 24.63 & 3.07 & 2.71 & \\
\hline
\end{tabular}

Anchorage capacity of the punched metal plate fasteners was calculated as a characteristic value. Some of the values, required to calculate the anchorage capacity of a fastener are given only in specific fastener's Declaration of Performance. The latter values are given as characteristic and can not be converted to an average as no information concerning standard deviation is provided. The characteristic values of experimental results are calculated according to EN 14358. Mean value and standard deviation of experimental results are used. The characteristic anchorage strength $(22.49 \mathrm{kN})$ calculated from experimental test results for type $A$ specimens was $15 \%$ higher for joints with the secondary used punched metal plate fasteners and $100 \%$ higher $(39.13 \mathrm{kN})$ for joints with the new punched metal plate fasteners when compared with the theoretical value according to Eurocode 5 characteristic anchorage capacity $(19.6 \mathrm{kN})$. For type $B$ specimens the experimental characteristic anchorage strength was $59 \%$ higher $(14.44 \mathrm{kN})$ for the joints with the secondary used punched metal plate fasteners and $171 \%$ higher $(24.63 \mathrm{kN})$ for joints with the new punched metal plate fasteners when compared with the theoretically calculated according to the Eurocode 5 characteristic anchorage capacity $(9.1 \mathrm{kN})$. It is likely that the characteristic experimental anchorage strength of the punched metal plate fasteners was higher than the calculated characteristic anchorage strength because production control during production of specimen was high which led to decrease of deviation of specimens.

Theoretically determined results of slip modulus $\mathrm{K}_{\text {ser }}$ for whole joint and slip modulus $\mathrm{k}_{\text {ser,mean }}$ for metal plate fastener are shown in Table 4. Fastener's slip modulus in type $A$ joint - parallel to timber grain is higher than declared, while in type $B$ joint - perpendicular to timber grain is smaller than declared.

Table 4. Slip modulus according to Declaration of Performance of fasteners and experiment's results

\begin{tabular}{|c|c|c|c|c|c|c|}
\hline Joint & 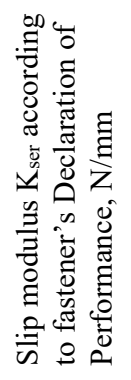 & 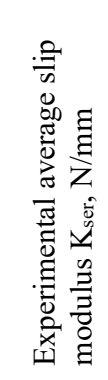 & 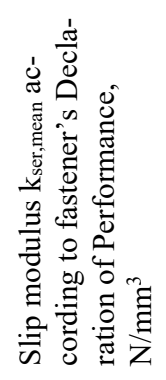 & 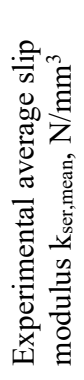 & 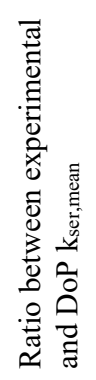 & 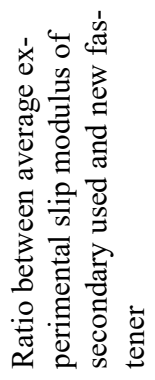 \\
\hline Type A Secondary used fasteners & 41447 & 44170 & 11.1 & 12.7 & 1.14 & \multirow{2}{*}{0.88} \\
\hline Type A New fasteners & 41447 & 53780 & 11.1 & 14.4 & 1.30 & \\
\hline Type B Secondary used fasteners & 29787 & 21980 & 11.1 & 8.2 & 0.74 & \multirow{2}{*}{1.14} \\
\hline Type B New fasteners & 29787 & 19380 & 11.1 & 7.2 & 0.65 & \\
\hline
\end{tabular}

\section{Conclusions}

1. This article investigates the possibility of reuse of timber structures with punched metal plate fasteners. The Secondary use of punched metal plate fasteners would be able to greatly decrease the wastes of used and no longer needed timber structures. 
2. The laboratory experiments done according to EN 26891 show that the timber joints connected with secondary used punched metal plate fasteners are capable to sustain up to $80 \%$ of tension load comparing with the new fasteners. The obtained results show that the stiffness of joints decreased by about $18 \%$ when the fasteners were connected parallel to the timber grain and increased by around $12 \%$ for fasteners which were connected perpendicular to the grain.

3. The obtained results on a small number of specimens in each series show a great potential for the future research taking a higher number of samples in each series performed and to carry out more different test configurations, such as: investigation of tension, compression and shear capacities and stiffness parallel and perpendicular to the main axis of the secondary used punched metal plate fasteners; investigation of anchorage capacities and load-slip characteristics in compression, tension and shear when load is in parallel and perpendicular to the main axis of the secondary used fasteners.

\section{References}

Alter, L. (2019). Lighten up: Primary steel production is responsible for up to 9 percent of $\mathrm{CO}_{2}$ emissions. Retrieved from https://www.treehugger.com/climate-change/lighten-primary-steel-production-responsible-9-percent-co2-emissions.html

Ellegaard, P. (2006). Finite-Element modeling of timber joints with punched metal plate fasteners. Journal of Structural Engineering, ASCE, 132(3), 409-417. https://doi.org/10.1061/(ASCE)0733-9445(2006)132:3(409)

Jurgelionis, Ž. (2011). Investigation of fire resistance of timber trusses with punched metal plate connections. Vilnius Gediminas Technical University.

Kundak, M., Lazic, L, \& Crnko, J. (2009). CO 2 Emissions in the steel industry. Metalurgija, 48(3), 193-197.

Lietuvos standartizacijos departamentas. (2000). Timber structures - Joints made with mechanical fasteners - General principles for the determination of strength and deformation characteristics (ISO 6891:1983) (EN 26891:2000).

Lietuvos standartizacijos departamentas. (2010). Timber structures - Product requirements for prefabricated structural members assembled with punched metal plate fasteners (EN 14250:2010).

Lietuvos standartizacijos departamentas. (2016). Structural timber - Strength classes (EN 338:2016).

Lietuvos standartizacijos departamentas. (2016). Timber structures - Calculation and verification of characteristic values (EN 14358:2016).

Mykolaitis, D. (2018). Application for a patent No.: LT2018 569, A tool for the extraction of a punched metal plate fastener from a timber structure and the method of extraction.

MiTek. (2013). Declaration of performance (No: DoPGNT100S).

Nae Hee Han. (2018). The circular economy: implications for the steel industry. Retrieved from https://www.worldsteel.org/media-centre/blog/2018/circular-economy-implications-steel-industry.html

NASA. (2014). Global climate change. Retrieved from https://climate.nasa.gov/causes/

Tinozivashe, Z., \& Zhongwei, G. (2011). Numerical modelling for sensitivity analysis of wood joints made with double-sided punched metal plate fasteners. Advances in Structural Engineering, 14(2), 163-177. https://doi.org/10.1260/1369-4332.14.2.163

World Steel Association. (2015). Steel in the circular economy. A life cycle perspective. $32 \mathrm{p}$. Retrieved from https://www.worldsteel.org/en/dam/jcr:00892d89-551e-42d9-ae68-abdbd3b507a1/Steel+in+the+circular+economy+-+A+lif e+cycle+perspective.pdf

Žikica, T. M., \& Saša, Đ. M. (2014). Experimental determination of load bearing capacity of connections realized by punched metal plate fastener. Technika, 69(5), 735-741. https://doi.org/10.5937/tehnika1405735T 